\title{
Editorial: Cutting the Mustard
}

I

The most solid fact to be learned at the 18th World Congress of Philosophy in Brighton in August was that the 19th Congress will be held in Moscow in 1993. Even a solid fact can provoke philosophers into controversy. Julius Tomin, refugee philosopher from Czechoslovakia, announced that the Soviet authorities would allow him to go to the Moscow Congress only if he resumed his Czech citizenship or acquired British citizenship. He feared he would have to miss that Congress. He went on to speak of Aristotle's idea of 'free time' (scholè) and to contrast it with the dehumanizing unemployment that prevails in modern societies where philosophy is treated as dispensable. The chairman, Professor Evandro Agazzi, ruled that these facts and comments were not relevant to the theme of the session, 'Human Beings as a Subject Matter of Philosophy'.

In the first plenary session Professor Elizabeth Anscombe asked us to consider why a chair feels no pain and why a pencil has no uncles, and used our unspoken answers to expound Wittgenstein's notions of grammar and essence. Soon we were involved in debates about innate ideas from Plato to Chomsky, and about the essence of man from Aristotle to modern physicalists and existentialists. Evolutionary accounts of the origins and growth of language were dismissed because 'they do not explain, they simply say that it happened'. With little more than hints of a theology held in reserve, she sketched another kind of explanation. The capacity for language must belong to whatever created that capacity in us, unless its creator, without having our linguistic capacity, has another form of intelligence than the one we are here to employ and to understand. For good measure Professor Anscombe offered the result of an experiment and its consequences for a question of historical scholarship. She once put to a nine-year-old American girl all the questions Socrates puts to the slave in Plato's Meno, and was given all the same answers. So there is at least one passage in Plato that is not a fiction.

\section{II}

Is it lawful to eat whalemeat on Fridays? This question had been little discussed since the thirteenth century until it was revived in the medieval philosophy section of the Congress. The philosophical point of it is more directly raised by the example of the language in which the 


\section{Editorial}

word for 'bird' is also applied to insects and to aeroplanes: Is classification natural or artificial, grounded or arbitrary? Plato's 'exaggerated realism' raises the spectre of an abstract and heavenly Dog whose nature is only sketchily copied in Rex or Rover, as the triangle on the blackboard is the ragged shadow of the genuine Euclidean article. Nominalism over-reacts into making the world less tidy than it is, as if it were impossible to confuse Tweedledum with Tweedledee.

A reader or hearer often catches the intriguing or bizarre example without seeing why it matters for its purpose. Descartes melts a piece of wax to help him to understand the relation and the distinction between substance and qualities. Berkeley contemplates the tree in the quad, or the bowl of lukewarm water into which he puts his cold left hand and his warm right hand. His strategic purpose is to understand the nature and reality of the objects of perception. Heraclitus makes concrete his concern with identity in the flux of nature when he pronounces that 'You can't step into the same river twice', only to be capped by his disciple Cratylus, who added that you cannot step into it even once. A philosopher's examples are the cash without which his generalizations are cheques backed by nothing in the account. The notorious fuss about the angels on the head of a pin makes sense when put into its theological and historical context. If matter is what divides individual from individual, and angels have no matter, then every angel is a specimen only by constituting a whole species.

Many such examples also reveal the origins of philosophy in our own non-specialist understanding of thought and language and the world. Outside formal philosophy we tease children with 'tomorrow never comes', or with this syllogism: 'Any cat has one more tail than no cat. No cat has two tails. Therefore any cat has three tails'. There are instructive fantasies for grown-up people too. Swift writes about men by writing about beings too big to be men and beings too small to be men. There is a sharp philosophical point to his tale about the architect who starts with the roof and works downwards to the foundations, like 'those two prudent Insects, the Bee and the Spider'. Borges creates a man who creates a novel that consists of the same words in the same order as Don Quixote. Lewis Carroll is full of examples: running fast to stay in the same place; a cat that goes away but leaves its grin behind; a map on the scale of one mile to the mile. Carroll was a mathematician and a logician, a descendant of Parmenides and of Zeno, who denied the possibility of motion or change or variety or plurality, and proved the point by showing that Achilles cannot catch the tortoise, that the arrow can never reach its target. Carroll was also a precursor of Russell, one of whose contributions to logic and to mathematical philosophy was to ask his question about the class of all classes that are not members of themselves. 
If a mathematician nevertheless upbraids you with the unreality of the examples used by flighty philosophers it is useful to recall this old question from a mathematical scholarship paper: 'Consider an elephant (whose mass may be neglected) ...'

\section{III}

The Wednesday of the Congress was funny coincidence day. The first funny coincidence was the case of the absent interpreters. No translation into Russian-one of the five official languages of the Congresswas provided for the five o'clock lecture in the main hall of the Brighton Centre. By a coincidence, the lecturer was Sir Karl Popper, author of The Open Society and its Enemies, a classic plea for glasnost, published when that word was less well known in the West and less prized in the East than it is today. The translation service into Russian was being provided by the Soviet delegation itself. The other four languages were served by professional translators from the United Kingdom. Most of the Soviet delegates decided that they would like to go sightseeing. They gave their interpreters a half holiday. This left in the lurch the Chinese and some Japanese and other Asian philosophers who were relying on the Russian version.

The second funny coincidence was that this happened just an hour or two after the General Assembly of FISP-the International Federation of Philosophical Societies - had ratified the decision to hold the 1993 Congress in Moscow. There is no official indication of what the translation arrangements in Moscow will be like. Academician I. T. Frolov did not touch on the question when he gave his valedictory lecture on 'Perestroika: Its Philosophical Meaning and Human Purpose'.

The FISP General Assembly is not unlike the United Nations General Assembly. Small nations propose, super-powers dispose. The American Philosophical Association strongly supported the acceptance of the Moscow invitation. In return, everything seems set for the 1998 Congress to be held in Atlanta, Georgia. Professor Odera Oruka and his Kenyan colleagues presented a persuasive case, but they will have to wait at least until the twenty-first century for the chance to host the first World Congress to be held in Africa.

Politics and ideology are not the only sources of conflict between philosophers. Popper recalled that when he read some of Rudolf Carnap's work on probability theory he felt as parents feel when their son or daughter joins the Moonies. But at least Popper and Carnap understood each other, and shared some mathematical and philosophical methods. Some delegates at Brighton regarded each other like aliens from another space. If opponents are too far apart there is mutual 


\section{Editorial}

incomprehension rather than conflict. Combat involves contact with the enemy. A battlefield is common ground.

The recognition of common landmarks makes disagreements more statable and intelligible. In papers and discussions the names of Plato and Aristotle, Kant and Hegel, Locke and Descartes, recurred on the lips of philosophers from all the continents. Professor Jurgen Habermas of Frankfurt made use of Leibniz's notion of the complete concept of an individual in his plenary session paper on 'History, Society and Person'. His paper was disciplined and humane, while so many were one or the other or neither. There were disputes about what the classic thinkers meant, and about whether it was true or false, but the shared texts made possible a common discourse in which points were made and sometimes conceded. Notoriously, after the few classic names, all is contested. Some prefer Gadamer to Gandhi, others Derrida to Dummett.

If philosophical dialogue did not have its dialectic structure it would deserve all the most extreme insults about its fruitlessness. Dialogue allows reservation and qualification and therefore complexity in description. This kind of collaboration takes the form of conflict, so Professor Richard Hare was at least half right when he spoke of the Congress as a kind of intellectual Olympic Games. Rival religions, ideologies and metaphysical doctrines will continue while there are human beings, but that does not show that there is no truth to be sought and sometimes found. It is clear to all of us that it is possible to be wrong, and that means we have to find room for the notion of being right.

Even the concept of human nature - the unifying theme of the whole Congress - is a battleground. Some, like the existentialists, repudiate it as a tyrannical concept, used only by those who wish to rough-hew us all into the same shape. Others acknowledge that human variety need not obscure the unity of the species and its understanding, including its philosophical understanding. Whenever understanding has been enlarged in these meetings it has been because of honest effort using native gifts, training and experience--and not just a funny coincidence.

\section{IV}

What is the meaning of it all? Philosophers attending the World Congress in Brighton asked this question about the cosmos. They also asked it about the World Congress. And what was the meaning of all the media coverage? Wittgenstein said that the philosopher is not a citizen of any community of ideas; that is what makes him a philosopher. Pascal recommended more time spent alone in one's room. The 
Brighton Centre was built for prime ministers and tycoons, not for solitary thinkers.

Some of the Brighton delegates are tycoons. They travel the world from congress to congress, cutting no philosophical mustard but selling the product or the salesman. These are the stuff of which presidents and secretary-generals of international organizations are made. Their critics mutter about gravy trains and the jamboree factor.

There was a jamboree for all of us on the Thursday evening at the Congress dinner. Professor Vladimir Mshvenieradze replied to the toast of FISP in a speech without notes, but with philosophical wit and Georgian humour.

Much serious philosophy was done in the Congress. The 200th anniversary of the publication of Kant's Critique of Practical Reason was marked in a colloquium in which Professor Stephan Körner and Professor A. Phillips Griffiths collaborated with two Warsaw Pact representatives. In another room at the same time Professor John Passmore, chairing the symposium on the question 'Are There Cultural Universals?', was distinguishing the role of the philosopher from the role of the anthropologist, and urging philosophers to pay as much attention to the social sciences as to the natural sciences. After all, it is man who is the subject of our story.

We now leave the Centre and the spotlight to the eager politicians. For them there will be flowers not foliage round the platform. As we go back to our daily work some of us reflect that it is better when two or three are gathered together rather than a thousand. The prospect of smaller departments, much bewailed in public print, may not be so bad after all. Those who have become unused to such small-scale surroundings are all the more in need of a retreat into the Pascalian chambre.

As to the public and our image, we have always known that philosophers are regarded ambivalently by powers and by persons. Sometimes they crown us with laurel, and sometimes they dose us with hemlock.

Lord Quinton, proposing the toast of FISP, spoke the last word on what a congress can achieve. In his earlier days as an Oxford philosopher he noticed in the Bodleian Library a copy of the Proceedings of the 7th World Congress, held in Oxford in 1930. The volume contained a short paper by the eminent Polish philosopher Tadeusz Kotarbiński. Those six pages, Quinton testified, radically changed his philosophical outlook. As it is written, the Kingdom of Heaven may be likened unto a grain of mustard seed. 